\title{
THE IDIOMATICITY OF ENGLISH AND ARABIC MULTI-WORD VERBS IN LITERARY WORKS: A SEMANTIC CONTRASTIVE STUDY
}

\section{Prof. Dr. Hussein Hameed Ma'yuuf (Ph.D.) ${ }^{1} \quad$ Hasan Ali Hussein $^{2}$}

${ }^{1}$ English Department, College of Education for Human Sciences, Babylon University, Iraq. Email: husm56@gmail.com

${ }^{2}$ Department of English, Mazaya University College, Iraq

Email: hass29000@gmail.com

HNSJ, 2022, 3(1); https://doi.org/10.53796/hnsj3145

Published at 01/01/2022

Accepted at 27/12/2021

\begin{abstract}
The current study is mainly concerned with a linguistic contrastive analysis of one specific feature of grammar and vocabulary in both English and Arabic languages, which is an integration of lexical verbs with adverbial and/or prepositional particle(s), which are widely known as multi-word verbs in the English novel (East of Eden) by John Steinbeck (1952) and the Arabic novel (Palace of Desire) [Qasr Alshawq] by Naguib Mahfuz (1957).

Furthermore, the study seeks to demonstrate that there are basic similarities and differences between English and Arabic multi-word verbs. Such parallels and differences are examined in depth through a theoretical comparison of these combinations in both languages and analysis of the aforementioned novels.

The current study is divided into five sections: It begins with an introductory one in which the concept of multi-word verbs is introduced in both languages, followed by the objectives, research question, hypothesis, procedures, study limitations, and importance of the study. The second section is devoted to the theoretical underpinnings of multi-word verbs in English and Arabic, respectively. It explains that an English multi-word verb is a combination of two or three items (verb + adverb, verb + preposition, and verb + adverb + preposition) that works as a single unit of meaning in that its meaning cannot be deduced from the sum of its individual components' meanings.

The semantic attributes include the following characteristics: they are classified as non-idiomatic, semi-idiomatic, or idiomatic MWVs, with meanings ranging from the most non-idiomatic to the most idiomatic. The idiomatic type can be replaced with a one-word synonym. Furthermore, the particle has a significant impact on the meaning of the verb with which it is combined, in the sense that they fuse together and sacrifice their essential meanings to generate a new semantic unit. Finally, EMWVs exhibit polysemy in that every idiomatic MWV can have up to ten or more various interpretations depending on the context in which it is employed.

Section three is intended to outline the methods used in data analysis, while Section four is an examination of the target verbs in the above mentioned novel. Finally, part five presents the conclusions, findings, and recommendations for further research.

The current data analysis employs Quirk et al. (1985) and Celce-Murcia and Larsen-Freeman (1999) as a theoretical model for the examination of English multi-word verbs in Steinbeck's English novel (East of Eden). While Wright (1996) is also used as a theoretical model for analyzing Arabic multi-word verbs in Mahfuz's Arabic novel (Palace of Desire) [qasr alshawq]. Furthermore, Cowie (1993) is used as a practical model for MWV analysis in both languages.
\end{abstract}

Key Words: Multi-words, English Multi-word Verbs, Arabic Multi-Word Verbs, idiomatic, Semiidiomatic, Non-idiomatic, Semantic Features. 


\section{Introduction}

English multi-word verbs (henceforth EMWVs) are verb-preposition-adverb combinations that can have two meanings: idiomatic and non-idiomatic (Swan and Walter, 2001, p.138 ). However, Arabic multi-word verbs are the consequence of the above combinations but without the use of an adverb, i.e. ( lexical verb plus a preposition).

EMWVs are one of the primary challenges that English learners and translators have when translating such idiomatic phrases or verbs into their native languages. This is due to the semantic complexity of such troublesome statements.

Al-Khalaili (1979, p.5) confirms what has already been said by noting that, while being grammatically easy in many aspects, the English language poses a significant challenge to Arabicspeaking learners, particularly in its colloquial usage of a verb followed by a preposition or a particle. The current contrastive investigation is motivated by this challenging region of the two languages.

The current study attempts to demonstrate the semantic features of multi-word verbs in both English and Arabic in order to determine the similarities and differences between the two languages in respect to this sort of verb. A collection of research questions has been proposed in order to meet the study's defined aims and to investigate the established hypotheses. They are as follows:

1. What are the definitions of multi-word verbs in English and Arabic? What are these verbs called in both languages?

2. What are the primary semantic characteristics of multi-word verbs in the two languages?

3. What are the parallels and differences in multi-word verbs between English and Arabic?

4. In which of the formal languages are these verbs used?

5. Are there structures in Arabic that are analogous to the EMWVs?

6. Unlike English grammarians, Arabic grammarians do not categorize (verb-preposition), (verbadverb), and (verb-adverb-preposition) formations under a specific heading. As a result, the debate is whether they may be classified as MWVs. Do they also fit the semantic requirements for EMWVs?

The following hypotheses are advanced in this study:

1. Because there is no 'multi-word verb' heading in Arabic, this study hypothesizes that (Arabic twoword verbs, verb-preposition expression, and transitive verbs with a preposition) are equivalent to English multi-word verbs, so the researchers presume that the target Arabic verbs are multi-word verbs as well, based on previous research.

2. Furthermore, this study hypothesizes that the target verbs in the two languages differ in form but are identical in content.

3. Idiomatic usage of multi-word verbs in texts in both English and Arabic is projected to be much higher than non-idiomatic use.

4. Unlike English, which emphasizes EMWVs as one of the most significant sorts of idiomatic phrases, Arabic does not classify them as such.

The following techniques were used in the current study:

1. Providing a variety of definitions of multi-word verbs, their structures, and semantic aspects in both English and Arabic.

2. Explaining the different sorts of multi-word verbs in both languages from a semantic standpoint.

3. Comparing English and Arabic texts to emphasize the commonalities and contrasts in the usage of multi-word verbs in the two languages.

4. As a theoretical model for English language, Quirk et al. (1985) and Celce-Murcia and LarsenFreeman (1999) are used to investigate thirty quotes from the two novels chosen as samples in this study. Wright (1996), on the other hand, is used as a theoretical model for Arabic multi-word verbs. Cowie (1993) is used as a practical model for analyzing English multi-word verbs as well as Arabic ones.

The current study intends to accomplish the following objectives: 
1. Studying multi-word verbs in English and their Arabic counterparts for the goal of contrastive analysis.

2. Using context to demonstrate the many meanings of the target verbs, as well as the most valuable and often used multi-word verbs in both English and Arabic. It may also introduce foreign learners to such verbs in both languages.

3. Examining the semantic characteristics of multi-word verbs in both English and Arabic.

4. Examining the several sorts of MWVs (idiomatic, semi-idiomatic, and non-idiomatic) in English and Arabic literature.

5. Giving several instances in both languages.

6. Recognizing MWVs by identifying the primary points of similarity and difference between the two languages.

In addition, the paper is confined to semantic English multi-word verbs and their Arabic equivalents, as well as their practical application in two novels: (East of Eden) by John Steinbeck (1952) and (Palace of Desire) [Qasr AL-shauq] by Naguib Mahfuz (1957). The study is also limited to the first two chapters of the two novels since these two chapters include enough data to be evaluated and the results could be generalized.

The contributions of this work to the linguistics knowledge base are twofold:

1. It provides a semantic classification of MWVs. This category raises awareness of the issue and, ideally, serves as a platform for academics, translators, lexicographers, and educators to improve their tactics for dealing with this problem.

2. It conducts large-scale experimental research to analyze EMWVs and AMWVs. The huge number of utterances (30 quotes) and multi-word verbs acquired give a trustworthy quantity of data for this study, allowing the researchers to reliably verify the occurrence of the aforementioned phenomena in both languages.

\section{English Multi-word Verbs}

Linguists, grammarians, lexicographers, and pedagogues in English have approached multiword verbs in a variety of ways. These authors define such verbs as verbs composed of a succession of lexical units. They are also characterized as fixed phrases whose meanings are not predicted from the meanings of their components, or a multi-word verb is an expression that acts as a single unit and whose meaning cannot be obtained from the meanings of the individual pieces (Hart,1990,p. 1).

One of the most challenging challenges for English learners and non-native speakers is multiword verbs (Nasir, 2015, p.1). They appear simple at first look to a non-native speaker, yet their meanings might differ from what one would assume.

According to English linguists and grammarians, in order to be skilled and fluent in English, you must learn the capacity to employ MWVs correctly. However, understanding and using multiword verbs requires a level of expertise that is difficult for a non-native speaker of a given language to achieve (Turton \& Manser, 1985,p.6). As a result, Wallace (1981, p. 5) observes that when it comes to learning English, these phrases pose a challenge to the foreign student. Idiomatic English multi-word verbs are a sort of MWV that causes specific difficulties for learners ( henceforth IEMWVs).

\subsection{Definitions of MWVs in English}

According to Live (1965, p. 428), MWVs are a significant category of fundamental verbs, each of which is strongly associated with an adverbial or prepositional particle in such a way that the two parts may be seen as creating a single discontinuous verb. According to Heaton (1965, p. 127), an adverbial particle connects with a verb to generate a collocation with a new meaning. Each multiword verb must be treated as a separate entity.

According to Bolinger (1971, p. xxi), MWV is a lexical unit in the precise sense of a nonadditive compound or derivative with a set of meaning that is not the sum of its parts' meanings. In Sroka's (1972, p.14) terms, MWV is the verb and particle, or the verb and a collection of particles, which are claimed to create a type of integral functional unit in this situation. Furthermore, McArthur 
and Atkins (1974, p. 5) described such phenomena as combinations of basic monosyllabic verbs (put, take, get, etc.) with members of a collection of particles (on, up, out, etc.).

According to McArthur (1975, p. 9), a multi-word verb is constructed by combining a basic verb plus one of many particles. The outcome is referred to as 'Multi-word' since it appears to be a phrase rather than a single word. Although it appears to be a phrase, it is only a single word.. Similarly, Turton and Manser (1985, p. iv) define MWV as a verb with two or three independent components, such as "run away," "come in," "look forward to," and so on.

\subsection{Semantic Features of English Multi-Word Verbs}

This section offers descriptions and discussions of the semantics of the verbs and particles in relation to the semantics of multi-word verbs. Many multi-word verb roots are monosyllabic, and they are typically verbs for effect, motion, giving, being, or doing verbs (McArthur, 1992, p.772). One basic verb can be combined with more than one particle to form a variety of multi-word verbs, e.g. ( get up, get out, get off, get on). While the type of verb root that generates multi-word verbs is often restricted to a few semantic classifications.

The multi-word verbs themselves are not that limited (McArthur, 1992, p.772). According to Dixon (1992, p.294), the resultant multi-word verbs are divided throughout a larger range of kinds; some of them have extremely abstract and specialized meanings for which there is no monomorphemic counterpart, e.g. let $X$ in for $Y$, see $X$ through $Y$, take up with X".

According to McArthur (ibid., p.775), the verb-particle combination is semantically unified. As according to Kolln and Funk (2012, p. 40), multi-word verbs are only those combinations that constitute an idiom whose meaning cannot be derived from the meaning of its parts. In this sense, Parrot (2010, p.108) regards the multi-word verb as an indivisible single unit of meaning composed of two components (a verb plus a particle).

Thus according to McArthur (1992, p.773), multi-word verbs can be classed as (non-idiomatic) or metaphorical (idiomatic). He (ibid.) illustrates the two categories with the following examples:

1. She put down the book (non-idiomatic) (ibid.).

2. The army put down the rebellion (figurative/idiomatic) (ibid.).

Therefore, the particle differs from the preposition in that the particle can influence the meaning of the verb with which it is semantically associated and lends a figurative meaning to that verb, but the preposition does not change the verb's literal meaning. This is due to the fact that while the verbparticle combination may not be multiple in one context, it can be multiple in another, as seen below:

3. She took in the box. 'brought inside'(literal meaning)(ibid., p. 1154).

4. She took in her parents. 'deceived' (idiomatic meaning) (ibid.).

In terms of semantic aspects, Murphy (2012, p. 274) says that particles such as (on, off, out, etc.) are employed with verbs of movement, such as:

5. The bus was full. We couldn't get on (ibid.).

6. Sarah is leaving tomorrow and coming back on Saturday (Murphy, 2012, p, 274).

According to McCarthy and O'Dell (2004, p.8), it is possible to think of multi-word verbs as separate entities. They can frequently, but not always, be substituted with a one-word equivalent, keeping in mind that single-verb synonyms are sometimes more formal, i.e. Table (1): Multi-word Verbs Synonym

\begin{tabular}{|c|c|c|}
\hline No. & Multi-Word verb & Single-Verb Synonym \\
\hline 1 & Put off & Postpone \\
\hline 2 & Turn up & Arrive \\
\hline 3 & Take off & Remove \\
\hline
\end{tabular}

\subsection{Types of English Multi-Word Verbs}

In the this section, the multi-word verbs are going to be classified into semantic aspects. 


\subsubsection{Semantic Classification of EMWVs}

The study in this section would be focused with the semantic features of EMWVs. The goal here, as in the preceding section, is to build up a picture of the phenomena of EMWVs so that it can be compared to its Arabic equivalent.

In addition to categorizing MWVs according to syntax, English grammarians and linguists categorize them according to meaning, owing to the fact that they differ in how varied the structure that retains the unique meanings of the verb and the particle is (Quirk \& Greenbaum, 1973, p. 348).

When someone sees a multi-word verb, he or she can sometimes grasp the meaning of that verb if he or she understands the verb and particle separately. In light of the above, one interpretation of 'put down' is to put something somewhere, i.e.

7. Jack put the books dawn on the table (Parkinson, 2001, p. 184).

But what is the meaning of the following sentence?.

8. She's always putting people dawn.

It definitely does not imply that she puts individuals, but rather that she constantly criticizes them. As a result, since there is no way to interpret the meaning of the verb and the particle individually, it appears logical to assume that the form is idiomatic multi-word verb (Parkinson, 2001, p. 184).

Because the meanings of MWVs vary from non-idiomatic to idiomatic (Gries, 2002, p. 276), and their semantic kinds vary from the most literal to the most idiomatic, they can be semantically classed as follows:

\subsubsection{Non-idiomatic EMWVs}

The EMWV is more than just combining the underlying verb and the particle into a single word. Many verbs in English can be coupled with an adverb or a preposition; when these verbs are used literally with a preposition, they are straightforward to be understood, such as:

9. He walked across the square (Quirk et al., 1985, p. 662).

10. She opened the shutters and looked outside (ibid.).

As previously stated, both components of the combination retain their separate lexical meaning (Cowie, 1993, p. 39), for example:

11. Take it out ( ibid.).

12. Bring the box in (ibid.).

13. Put your hand up (ibid.).

\subsubsection{Semi-idiomatic EMWVs}

It manifests itself in the fact that one component of the formation retains its lexical meaning while the other is less clear (Quirk et al, 1985, p. 1162), for example:

14. Knock him out (ibid.).

15. Drink your milk up (ibid.).

16. I will find out the truth (Quirk et al, 1985, p. 1162).

Such multi-word verbs, like non-idiomatic verbs, can be comprehended by evaluating each word in the combination. However, the particle in semi-idiomatic multi-word verbs has a different meaning than one would be used to; as a result, they are referred to as semi-idiomatic multi-word verbs (Litvinov et al., 2017, p. 86). The particles indicate whether the verb action has been finished or is still in progress (Quirk, et al., ibid.). In the example below, (up) refers to (use) by showing that the oxygen has been utilized completely, i.e. to the point of completion.

17. Oxygen is used up by organisms faster than it can be replaced (Litvinov et al., ibid.). In the next example, (up) relates to ( $f i l l)$ by conveying that the dish is filled entirely, to the point of completion.

18. The ideal place for a soap tray is under the shower so it doesn't fill up with water (ibid.). In the final example below,(on) indicates that (play) should continue, that it is ongoing.

19. Referee waves play on(ibid.). 


\subsubsection{Idiomatic EMWVs}

The elements of the combination are opaque, and the complete meaning of the idiomatic MWV cannot be determined from the whole sum of the lexical meanings of its separate pieces (Quirk et al, ibid.; Celce-Murcia and Larsen-Freeman, 1999, p. 433; Cowie, 1993, p. 38), for example:

20. I will never give up (Cowie, ibid.).

21. He cannot put up with him anymore (ibid.).

The semantic categories of EMWVs are outlined in Table (2) below:

Table (2): Semantic Categories of EMWVs

\begin{tabular}{|l|l|l|}
\hline No. & Semantic Category of MWVs & Example \\
\hline 1 & Non-idiomatic & Adam has come back. \\
\hline 2 & Semi-idiomatic & She wrapped up her luggage. \\
\hline 3 & Idiomatic & The war broke out suddenly. \\
\hline
\end{tabular}

Scholars have assigned different labels to idiomatic and non-idiomatic MWVs. For example, McArthur (1975, p.36) refers to them as "literal and figurative," whereas Sawyer (1999, p. 5) refers to them as "Compositional and Non-compositional".

The meanings of the individual parts of an idiomatic multi-word verb tell us little or nothing about the meaning of the whole. For example, one may be relatively familiar with the meanings of the words 'pick' and 'up' as separate words, but he may be unable to understand the idiomatic meaning of MWV 'pick up' in a sentence such as:

22. Business is picking up (Turton \& Manser 1985, p. 8).

However, such a semantic classification of MWVs is controversial because the distinction between these categories is not always evident, and the same construction may fall into more than one category depending on the context (Swierzbin, 1996, p. 3). As a result, a closer examination of the extant literature reveals that researchers disagree in their approaches to addressing the phenomenon of MWVs in terms of what should be included/excluded from their coverage.

It is important to note that for the purposes of this study, the inclusive view of scholars for treating MWVs is being adopted, which includes the full range of combinations, i.e. the nonidiomatic and idiomatic types of both (verb + adverb) and (verb+ preposition) combinations, such as Kennedy (1967), Sroka (1972), and Celce-Murcia and Larsen-Freeman (ibid.).

It should be observed that the combinations of idiomatic MWVs are not generated freely; rather, they are governed by a number of "collocational limitations" (Palmer, 1974, p. 212). To be more specific, we cannot exchange particles for their polar opposites, i.e. we can put up with something, but at the same time, we cannot put down with it. We can look after someone, but we cannot look before someone(ibid.).

Cowie (1993, p. 38) proposes two criteria for distinguishing idiomatic from non-idiomatic MWVs; both tests are connected to meaning rather than syntax. The first step is to see if a single word may be used in place of the entire phrase. And the second is to inquire if the second word can be deleted, for example, to determine whether the MWV(fall out), as used in (I was delighted with the way things had fallen out), is an idiomatic or not, one of the criteria must be used. In actuality, the answer to the first test is yes, we may substitute (fall out) for one word, 'happen,' and the answer to the second test is no, we cannot remove the second half of fall out since its form is set and cannot be divided or broken up, it is an idiomatic MWV.

Many multi-word verbs occur inside semantic frames that are typically regarded as idiomatic. While the combination of the verb and the particle is frequently examined as extra modifications to the meanings of the root verbs, the combination of the verb and the particle may result in a meaning distinct from that of the base verb. Machonis $(2009$, p.2) refers to these more idiomatic multi-word verbs as 'frozen verbs,' i.e., break up the audience 'cause to laugh,' burn out the teacher 'exhaust'. On the other hand, compositional multi-word verbs, i.e., (drink up the milk, wipe down the countertop), can be argued to result from the combined meanings of the particle and the verb which add aspect to (ibid.). 


\section{Arabic Multi-Word Verbs}

The discussion in this section demonstrates the definitions, characteristics, and semantic categories of multi-word verbs in English. Similarly, Arabic contains linguistic aspects that have certain characteristics with English multi-word verbs (Alkhuli, 1999).

In Arabic, there are several constructions in which verbs are followed by prepositions, (يتوق الى (2) ( to crave ), ( يتحدث عن to talk about), (يعلّق على to comment on), ( يفكر في to think of) etc. In both written and spoken Arabic, these formulations are popular, frequent, and widely utilized. However, unlike English grammarians, Arabic grammarians do not categorize such constructs, hence the key question is whether they may be considered MWVs. And do they meet the previously stated semantic criteria for EMWVs?

Actually, Arabic has a similar phenomenon, but it does not allow verbs to combine with adverbs to form Arabic multi-word verb (henceforth AMWV), but rather allows them to merge with prepositions, as in: (مالَ إلىى mala 'ila ) which means (to like, to sympathize), and ( مالَ عَن mala 'an ) which refers to (avoid, dislike). Classical Arabic linguists have not classified these combinations, owing to the fact that they do not use prepositions while examining Arabic verbs (Aldahesh, 2017, p. 13).

Dawood examines all verb-preposition combinations in the Qur'an without regard for the idiomaticity of some and the non-idiomaticity of others (Aldahesh, 2017, p. 14). It is worth noting that "Al-ta'lluq" (relation or attachment) is a key aspect in forming the idiomaticity of Arabic verbpreposition pairings.

Al-Shamsan (1986), like Dawood, exhibits several fascinating ideas and offers handy tables of verbs and the prepositions with which these verbs often mix in his study of verbs in the Qur'an. However, another key component that contributes to the idiomaticity of Arabic verb-preposition pairs is transitivity and/or intransitivity (Aldahesh, 2017, p. 14).

The point to be made here is that the difficulty lies in the idiomatic type of Arabic verbpreposition combination, which has a metaphorical, figurative, and non-transparent significance, whereas the other type appears transparent and easy to understand and poses no difficulty to readers, commentators, and translators of Arabic language.

\subsection{Definitions of MWVs in Arabic}

Multi-word verbs are a form of verb that consists of a succession of lexical parts in both English and Arabic. The Arabic language consists of a linguistic item that has certain characteristics with English multi-word verbs ( Mubarak, 2015, p. 8).

Lentzner (1977, p.159) states that only "true" Arabic prepositions may join semantically with verbs and be important elements of verb-preposition combination in her attempt to investigate the link between verbs and prepositions in Arabic language. Lentzner refers to "true" prepositions such as ('alaa, ilaa, min, 'an, fii, bii and lii) which represent the core locative and directional ideas. According to Lentzner, such formations in Arabic exhibit properties that are comparable to both multi-word verbs and verb-preposition structures in English.

(ب bii) can work as a particle that changes intransitive verbs of motion into transitive verbs of transport, in addition to its function as an integral element of several verb-preposition idioms. However, Arabic grammarians refer to such functions of (بbii) as (بـ the transitivizing baa') or

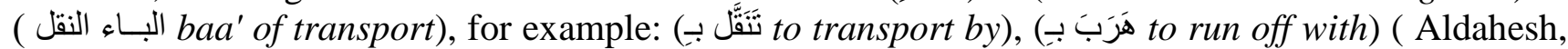
2008, p. 73).

Furthermore, there are some verbs known as (non-idiomatic multi-word verbs) that do not occur

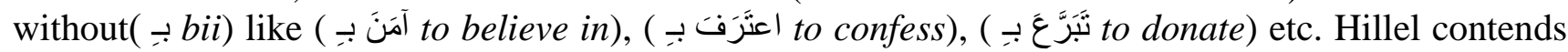
that the preposition is required for the meaning of the verb and is invariable, such that altering the preposition changes the meaning of the entire combination, i.e.

23. كثَفت عن الجريمة He exposes the crime) (Heliel, 1994, p. 145).

Versus

24. كَثَفَ على الحقيبة He inspect the bag)(ibid.).

According to Heliel, it is not too difficult to grasp the Arabic verb structure when it is employed with or without a preposition, i.e. (to follow him) vs. (to catch up with him). This is primarily because 
the verb in Arabic (verb + preposition) formations is occasionally utilized in non-idiomatic ways (ibid. ), i.e.

25. (مالت المركبة بالركّاب The vehicle tilted with the passengers)( ibid.)

Versus

26. مالت البنت الى امها) the girl tended towards her mother)( ibid.).

Because it is linked with the preposition (to), the verb (مالت) is non-idiomatic in the first phrase but idiomatic in the second. According to Najiib (2001, p. 71), MWVs do exist in Arabic. In addition, he provides the following instances to demonstrate them:

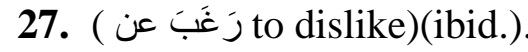

28. ( (

29. (مالَ إلى to like)(ibid.).

30. ( مالَ عن to dislike) (ibid.).

Because there are similarities in structure and idiomaticity between idiomatic English multiword verbs and idiomatic Arabic verb-preposition combinations, the idiomatic Arabic verbpreposition combinations are classified as idiomatic Arabic MWVs (henceforth IAMWVs). They undoubtedly comprise constructs that are comparable to IEMWVs in that they each create a single unit of meaning and reveal significant semantic links between the verb and the prepositions.

To answer the question posed at the beginning of this chapter, Lentzner (1977), Kharama and Hajjaj (1989), Alkhuli (1999), Najiib (2001), Bataineh and Bataineh (2002), and Nasir (2015) all agree that MWVs exist in Arabic. MWVs, on the other hand, establish a substantial phenomena in the English language, although the Arabic language does not recognize this occurrence as such. According to the findings of the preceding investigations, Arabic grammarians do not categorize the Arabic verb + preposition combination.

\subsection{The Semantic Features of AMWVs}

It should be noted that each preposition has its own meaning. It adjusts the verb's meaning in accordance with the noun that follows the preposition; hence, any verb may have more than one meaning according to the preposition that is linked to it. In this regard, consider the following example to demonstrate the aforementioned point of view:

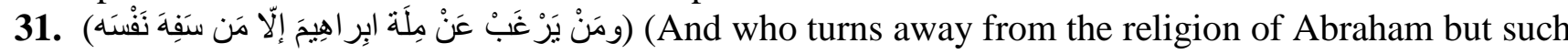
as debase their souls with folly?) (ibid., 18).

As a result, the meaning of the multi-word verbs above has changed owing to a change in the

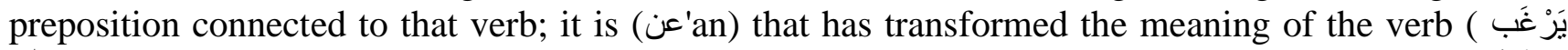

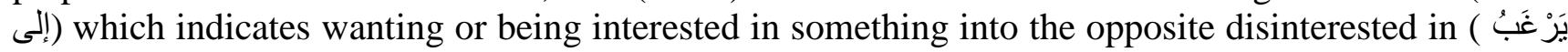
عَ). This type of impact is attributed to the preposition rather than the verb (Alkhutabi, et al.,1991).

\subsection{Types of Arabic Multi-Word Verbs}

AMWVs, like EMWVs, may be categorized based on semantic criteria.

\subsubsection{The Semantic Classification of AMWVs}

AMWVs may be categorized into three main semantic subtypes based on their usage at the semantic level. They are classified as idiomatic, semi-idiomatic, or non-idiomatic multi-word verbs.

\subsubsection{Idiomatic MWVs}

The idiomatic MWV is a kind of multi-word verb that is used to indicate an abstract meaning, for example, when the preposition (عن 'an) is appended to a verb, it has a meaning related to the idea of (about, or about(Mubarak, 2015, p. 11).

32. عَبَرَ عن تَأييده (He expressed his support) (ibid.).

Meanwhile, when coupled with a verb, the preposition (على) relates to a variety of meanings and appears in settings such as:

33. أخَذ على عاتِِِقه (He took it upon himself ) (ibid.).

Or

34. أخَذَ على يده العِلم (He learned from him personally) (ibid.).

According to certain experts, such as Abboud and McCarus (1968, p. 352), the idiomatic MWV is a verb-preposition combination in which the verb modifies its core meaning. Abboud and McCarus 
point out that in such cases, a verb-preposition idiom involves a single unit of meaning that is unique from the verb alone.

\subsubsection{Semi-Idiomatic MWVs}

It is worth mentioning that, in addition to the idiomatic and non-idiomatic varieties of AMWVs, there is a semi-idiomatic kind (Aldahesh, 2008, p. 87). Many Arabic verb-preposition formulations exhibit the semi-idiomatic type. The phrase (أعتَد على to depend on) is an example; this verb cannot be substituted for one word, and the preposition in this phrase cannot be omitted without producing a flaw in the overall meaning. This is owing to the fact that when combining with a preposition, the verb (10 اعَّد to authorize) sacrifices its meaning, whilst the preposition retains its core meaning. Because of this, this sort of Arabic construction is referred to be (semi-idiomatic) rather than idiomatic (Aldahesh, 2008, p. 87).

\subsubsection{Non-Idiomatic MWVs}

The third type of composition is verb-preposition, in which the verb retains its essential meaning, i.e. the verb ( آَََن to believe ) and the combination (آَنَ بـ believe in ) have the same meaning ( non-idiomatic).

\section{Methodology}

This section addresses the methods used in the contrastive semantic examination of multi-word verbs in English and Arabic. Each point is treated as a distinct item in the analysis, in the hopes that readers will comprehend such a language phenomena and that it will be well explored.

\subsection{Research Design}

In general, methodology is a framework used mostly by researchers to identify the techniques and amount of elements required in the analysis in order to provide a comprehensive and accurate sample of language (Meyer, 2004, p. 42). This type of framework is known as (Sampling Methodology), and it is established by a specific population about which generalizations are produced (ibid.). A population can be defined as all members of a well-defined class of things, people, events, and so on. A sample, on the other hand, is a subset of a population that is designed to be monitored (Ary et al., 2010, p. 148). The sampling approach, on the other hand, makes a study more exact and leads to the determination of the generalizability of the research findings (Showkat \& Parveen, 2017, p. 1).

From a linguistic standpoint, sampling methodology is an important part of the data processing process. It specifies the amount of samples needed to make the analysis an accurate picture of the genre or "population producing the texts" (Meyer, ibid.). Two major methodological categories must be differentiated during the data analysis process: probability and nonprobability sampling (Ary et al., 2010, p. 148). Probability sampling is a random sampling approach in which each element in the population has an equal chance of being chosen as a sample (Elder, 2009, p. 4). Each person in the population is assigned a number, and certain numbers are picked at random to be polled (ibid.). As a result, "simple random sampling, systematic sampling, and stratified sampling" are used in this approach (Kothari, 2004, p.15).

Nonprobability sampling, on the other hand, is not a random sample selection from a population; rather, "subjective procedures are utilized to decide which components are included in the sample" (Battaglia, 2011, p.523). Such subjective techniques are associated with aspects such as ease of use, common sense, representativeness, and bias avoidance (Gravetter\& Forzano, 2012, p.144).

The sequential sampling approach is one of the nonprobability sampling strategies. It is defined as "a complicated sample design in which the fundamental sample size is not fixed but is determined based on information collected over the course of the survey" (Etikan et al., 2015, p. 2). Using this approach, the researcher can pick an individual or a group of populations over a specific time period, perform his or her study, assess the results, and then, if required, select another group of people, and so on (ibid.). The use of nonprobability sampling is justified since it is well-suited to various forms of qualitative research. This is due to the fact that qualitative research is not necessarily concerned with generalizing the findings to a wide population.

In practice, the sequential sampling approach has various qualities that are both useful and favorable to researchers. Such a procedure is open and boundless in the sense that researchers can 
take samples one after the other for as long as they like (Kothari, 2004, p. 67; and Gupta \& Gupta, 2011, p. 50). As a result, it is regarded as a versatile and adaptive approach (Pan et al., 2014, p. 2).

In this work, the entire analysis employs a sequential sampling procedure based on nonprobability sampling methodology. As a result, the researchers correctly selects samples from the first two chapters of the two novels for analysis, ensuring that the majority of the textual quantity of each novel is covered.

The current study is a linguistic study to compare and contrast the use of MWVs in English and Arabic literature. The current study's methodology is a qualitative technique. The goal of qualitative analysis is often to improve knowledge of the quality, meaning, and features of the examined item or topic (Trochim, 2006, p. 205). As a result, the current study is qualitative in order to provide a knowledge of how multi-word verbs occur and appear in both languages.

It is worth mentioning that the goal of contrastive investigations includes both similarities and differences, with a concentration on differences (James, 1980, p.2). As a result, the current study is a contrastive one that looks at the semantic properties of English multi-word verbs and Arabic twoword verbs as a phenomenon in both languages as well as their different forms.

The current study's scope is limited to the semantic properties of multi-word verbs and a semantic classification. The following dictionaries were chosen for the current study: "NTC's dictionary of phrasal verbs and other idiomatic verbal phrases" written by Spears (2005) and "Oxford Phrasal Verbs Dictionary" written by Parkinson (2001) for English data, and Al-Ahmadi (1979) 'Mu'jam Alaf'al Almut'adia biharf' and Baalbaki (1995) 'Al-Mored: A Modern Arabic English Dictionary' for Arabic data.

\subsection{Data Collected}

The current study's data comprise sentences or utterances including multi-word verb combinations from two novels: (East of Eden) by Steinbeck (1952) and (Palace of Desire) [qar 1 shawq] by Maf (1957). Sentences from both novels having multi-word verbs are picked and evaluated, and two chapters from each novels are chosen to identify the multi-word verbs in them. However, the researchers here use the English-translated version of Arabic data translated by Hutchins et al. (1991) as a resource for readers who do not understand the Arabic alphabet.

\subsection{Methods of Data Analysis}

Quirk et al. (1985) and Celce-Murcia and Larsen-Freeman (1999) are used as theoretical models for the analysis of English multi-word verbs in Steinbeck's English novel (East of Eden) throughout the examination of distinct quotations from the two novels chosen as examples in this thesis. Wright (1996) is also used as a theoretical paradigm for analyzing Arabic multi-word verbs in Mahfuz's Arabic novel (Palace of Desire) [qasr al shawq].

Cowie (1993) is, nevertheless, used as a practical model for analyzing the two novels in the two languages. The two tests outlined in the preceding section and presented by Cowie (ibid.) will be used to determine whether or not English and Arabic verb-particle pairs are idiomatic. The first test is to replace the entire phrase with a single word. This leads to the assertion that if the 'verb-particle' structure can be replaced with a single word, it is an idiomatic multi-word verb. The second test is to remove the second word of the phrase; that is, can an English or Arabic preposition be removed without affecting the meaning of the phrase as a whole? If the response is no, it is an idiomatic multiword verb; if the answer is yes, the particle may be removed without changing the meaning of the expression, therefore it is non-idiomatic.

Following the same techniques as the models, the researchers evaluate the data in a similar but somewhat different manner. The distinctions. The distinctions are in the numbers and the content of the texts.

\section{Data Analysis}

The analytical processes outlined in section three are put into effect in this part. As a contrastive study, this section is divided into two sections: the first deals with the phenomenon of MWVs in English data and their meanings; and also their semantic aspects and semantic classifications. The second seeks to analyze the same issue in Arabic data, as well as to state the semantic characteristics and semantic kinds. 
As a result, this part goes through some contrastive analyses that might be used as a kind of qualitative demonstration for the two novels employed as the data under study. Furthermore, the effects of such a demonstration are explored later on. As samples of multi-word verbs, utterances from the novels mentioned above were chosen.

\subsection{Analysis of English Multi-word Verbs in "East of Eden" (1952)}

This practical section focuses on the English multi-word verbs, particularly the most commonly used onces, and their meanings in the well-known novel (East of Eden) (1952). All of the interpretations for these multi-word verbs are drawn from Spears's (2005) "NTC's dictionary of phrasal verbs and other idiomatic verbal expressions" and Parkinson's "Oxford Phrasal Verbs Dictionary" (2001).

\section{1. "To look through Dr. Gunn is to know the Hamiltons' medical history".}

- (look through): to examine the parts, pages, samples, etc. of something(Spears , 2005, p. 415). Looking up the verb and the preposition individually in a dictionary will not help you understand the meaning of this multi-word verb. The removal of the second half of the construction would change the meaning of the entire phrase, and (examine) is the word that has the same meaning as the current MWV, therefore such structure is idiomatic.

\section{2. "a gripping jaw set on its course even though the angels of God argued against it".}

- (Argue against): to make a case against someone or something; or to oppose the choice of someone or something in an argument(ibid., p. 18). The concerned multi-word verb is non-idiomatic, which means that the components of the combination are relatively evident, and the overall meaning of the MWV can be deduced from the lexical meanings of its separate parts. And deleting the second element has no influence on the verb's meaning.

\section{3. "Bearing her children did not hold her back very much".}

- ( hold back): to prevent sb/sth from moving forward or from entering or leaving a place ( Parkinson, 2001, p. 144). However, the overall meaning of the combination may have little or no relationship to the meaning of the individual words of the combinations, which is why (hold back) is correct to regard as an idiomatic term. The particle's mobility is an intriguing feature of this multi-word verb. Because a pronoun is employed as an object instead of a noun, it is inserted between the verb and the particle.

4. "It wasn't very long until all the land in the barren hills near King City and San Ardo was taken up".

- (take up): to adopt something new( Spears, 2005, p. 679). The aforementioned MWV is a fixed expression whose meaning is not predicted from the meanings of its components, making it an idiomatic multi-word verb; nonetheless, the particle affects the meaning of the multi-word verb in an idiomatic sense, and removing it results in a change in meaning.

5. "It is argued that because they believed thoroughly in a just moral God, they could put their faith there and let the smaller securities take care of themselves".

- (believe in): to trust or have faith in someone or something; to accept a fact or what someone says as truth(Spears, 2005, p. 40). This combination has a semantic meaning that can be deduced from the individual meanings of the verb and the preposition, making it an independent lexical item with non-idiomatic meaning. The results of the tests show that it is a non-idiomatic MWV, as there are no other words with the same meaning as this MWV, and the deletion of the particle has no effect on the verb's meaning (believe). 
6. "While many people came to the Salinas Valley pen-niless, there were others who, having sold out some-where else, arrived with money to start a new life".

- (sell out): to be sold until there is no more( Spears, 2005, p. 592). The construction consists of two elements: a simple verb and an adverb that serve as one unit of meaning; one component of the construction retains its lexical meaning while the other is less transparent; consequently, such a construction is referred to as semi-idiomatic.

7. "There were numbers of these families and they got the good land of the valley and cleared the yellow mustard away and planted wheat".

- ( clear away): to take something away(Parkinson, 2001, p. 50). Again, the composition is the consequence of two pieces coming together: a basic verb and an adverb that operate as one unit of meaning. Semantically, one component of the construction retains its lexical meaning, while the other is unclear and has a different meaning from the one to which someone may be used; consequently, such a composition is referred to as semi-idiomatic.

8. " He stumped in on a crude wooden leg he himself had carved out of beechwood".

- ( carve out of): to remove something from the inside of something else by carving or cutting(Spears, 2005, p. 88). In terms of the semantics of the MWV (carve out of), the components of the combination take on a new meaning when combined, and the overall meaning of the combination differs from the lexical meanings of its individual parts. However, both tests may be used here; the first refers to the potential of replacing the MWV with a lexical term that has the same meaning; in fact, the verb (sculpture) has the same meaning as the aforementioned MWV. While the second test is the removal of the particle, removing the MWV's postposition affects its meaning, indicating that it is an idiomatic MWV.

9. "He had in his pocket and placed on the parlor table the lead bullet they had given him to bite while they cut off his frayed leg".

- (cut off): to isolate something from some place or something(Spears, 2005, p. 138). The basic verb is joined with an adverb, and each part of the combination retains its sense; this is the non-idiomatic kind of multi-word verb types in terms of semantic frame or characteristics.

10. "Even then he was lucky, for the rebels retreated and the field surgeons moved up immediately".

- (move up ): to go higher( Spears, 2005, p. 444). The elements of this MWV retain their individual meanings, which form the meaning of the combination, thus it is a non-idiomatic MWV, such MWV is a single unit of meaning which is made up of two parts (a verb plus an adverb), to differentiate such kind of verb from the idiomatic one, the tests should be applied here, actually, deleting the second part of the verb shows that the verb means the same when it is combined with the particle, and this confirms the above.

11. "Cyrus Trask did have his five minutes of horror while they cut the shreds away".

- (cut away): to remove sth by cutting with a knife or a sharp tool( Parkinson, 2001, p. 68). With an adverb, the basic verb is employed literally. As a result, non-idiomatic MWV emerges from the combination of a verb and an adverb.

12. "He contracted a particularly virulent dose of the clap from a Negro girl who whistled at him from under a pile of lumber and charged him ten cents".

- (whistle at): to indicate approval or disapproval of someone or something by whistling (Spears, 2005, p. 755). In general, the EMWV is more than just combining the verb and the particle into a single word. Many verbs may be paired with an adverb or a preposition to make a multi-word verb; when these verbs are used literally with a preposition like (whistle at), they are termed (nonidiomatic) multi-word verbs and are easily figured out. It is simple to determine if a construction is 
non-idiomatic or idiomatic by substituting a word for that construction or eliminating the second unite of that construction; hence, deleting the particle of the current construction has no effect on the meaning of the base verb. As a result, it is an idiomatic MWV.

\section{3. "I'll make her so a drunk Indian won't take out after her".}

- (take out after) The elements of this MWV, when combined together, assume a new meaning which is (to begin to chase someone or something) (Spears, 2005, p. 673). The meanings of the individual parts, however, tell us little or nothing about the meaning of the whole. For example, one may be relatively familiar with the meanings of the words 'take,' 'out,' and 'after' as separate words, but he may be unable to understand the idiomatic meaning of MWV 'take out after' in a sentence such as: "I'll make her so a drunk Indian won't take out after her."

14. "By the time Cyrus was released from the hospital and the army, his gonorrhea was dried up".

- (release from): to liberate or let someone go from something( Spears, 2005, p. 555). The components of the combination have their own meaning, and the whole meaning of the combination can be obtained from the lexical meanings of its individual parts. However, by removing the postposition, the meaning remains the same, so it is non-idiomatic MWV. In relation to syntax, the construction is combined by a simple verb followed by a preposition.

- (dry up): to cure a skin rash by the use of medicine that dries (Spears, 2005, p. 179). The verb retains its concrete meaning in this category, but the adverb adds a subtlety that is indistinguishable from its core meaning. Although the specific meaning of this multi-word verb is unclear, a language student may understand the general meaning. As a result, such a category is known as semiidiomatic.

15. " because of this they could give God their own courage and dignity and then receive it back"

- (receive back): to get someone or something back (Spears, 2005, p. 550). This combination has a semantic meaning that can be deduced from the individual meanings of the verb and the preposition, making it an independent lexical item with non-idiomatic meaning.

Table (3): EMWVs in "East of Eden"

\begin{tabular}{|c|l|c|c|}
\hline No. & \multicolumn{1}{|c|}{ EMWVs } & Semantic Type & Alternative Verb \\
\hline 1 & Look through & Idiomatic & To examine \\
\hline 2 & Argue against & Non-idiomatic & \\
\hline 3 & Hold back & Idiomatic & To prevent \\
\hline 4 & Take up & Idiomatic & To adopt sth. \\
\hline 5 & Believe in & Non-idiomatic & \\
\hline 6 & Sell out & Semi-idiomatic & To be sold \\
\hline 7 & Clear away & Semi-idiomatic & Take sth. Away \\
\hline 8 & Carve out of & Non-idiomatic & To remove sth. \\
\hline 9 & Cut off & Non-idiomatic & \\
\hline 10 & Move up & Non-idiomatic & \\
\hline 11 & Cut away & Non-idiomatic & \\
\hline 12 & Whistle at & Idiomatic & chase sth. \\
\hline 13 & Take out after & Non-idiomatic & \\
\hline 14 & Release from & Semi-idiomatic & To cure a skin \\
\hline 15 & Dry up & Non-idiomatic & \\
\hline 16 & Receive back &
\end{tabular}




\subsection{Arabic Multi-word Verbs in (Palace of Desire) (1957) [Qasr Al-shaoq] by Mahfouz}

This section analyzes the Arabic multi-word verbs (AMWVs), i.e. (two- word verbs or transitive verbs via preposition), and their meanings in Mahfuz's Arabic novel (Palace of Desire) (1957) [Qasr Al shawq]. The researchers, however, use the English-translated version of the Arabic data translated by Hutchins et al (1991).

Furthermore, the (verb-preposition) formulations are checked in Al-(1979) Ahmadi's "Mu'jam Alaf'al Almut'adia biharf," and the translations of Arabic multi-word verbs into English are checked in Ba'albaki's "Al-Mawrid: A Modern Arabic-English Dictionary" (1995). It's worth reminding the reader that all Arabic multi-word verbs are of the (verb-preposition) variety. Furthermore, all of the verbs below are transitive via a preposition. Moreover, all verbs below are ' transitive by means of a preposition ', they can be separable or inseparable.

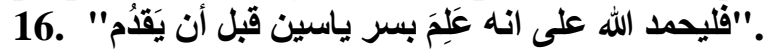

"Praise God that he had learned Yasin's secret before setting out"(Hutchins etal.,1991,p. 5).

- (عَلمَ بـ) (Al-Ahmadi., 1979 p. 248): to know( Ba'albaki, 1995, p. 775). This verb is an example of many typical multi-word verbs with non-idiomatic meanings that may be deduced from the two components of the combination. Furthermore, the verb is a transitive non-separable verb.

17. " "لم يَنَل الكِبَرَ من شعرِ ها ولا شحمها ولكن شابت ملامحها جهامةًَ واخثوشنت قسماتُها ".

" Age had not affected her hair or her plumpness, but her appearance had taken on an air of gloom and her features seemed coarser"(Hutchins et al., ibid., p.8).

- (نال من) (Al-Ahmadi., ibid., p. 404): to affect (Ba'albaki, ibid., p. 1154). When the components of the combination are merged, they take on a new meaning, and the whole meaning of the idiomatic MWV cannot be determined from the sum of its constituent lexical meanings. By modifying the preposition, the meaning shifts to something different, such as ( to give بونى جنالَ بـ (اعلى )(ibid.).

18. "تواصل العمل- بصمت- حتى توقفت ام حنفي عن العجين".

"They continued the work in silence until Umm Hanafi finished kneading the dough" (Hutchins et al., ibid., p. 8).

- (توقَتَ عن) ( Al-Ahmadi, ibid., p. 439): to stop (Ba'albaki, ibid., p. 392). This MWV has an idiomatic meaning that differs from the same verb when coupled with another preposition, such as (to hesitate (نَوَفَّنَ في . Another term that may be used in place of this MWV to demonstrate its idiomatic character is (to quit كَفَّنَ عن ).

19. "ثر غرَسَت يايها بالجرة

" She planted her hands in the bowl once more to resume punching the dough"(Hutchins et al., 1991, p. 8).

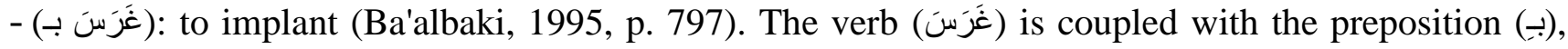
and they both have a non-idiomatic sense, thus it (the combination) is also a non-idiomatic expression.

20. "فابتسمت ام حنفي، وهي تومئ بذتنها الى سيدتها".

"Umm Hanafi smiled, gestured toward her mistress with her chin" (Hutchins, ibid., p. 9).

- (أوماً إلى)( Al-Ahmedi, 1979, p. 443): to make a sign or signal( Ba'albaki, ibid., p. 211). The present MWV is an idiomatic statement because it contains a synonymous term (to signal انشار), making it idiomatic.

21. "يَحَزْ في نفسي يا أُمي أنه عاد إلى سيرته".

" It tears me apart, Mother, that he's gone back to his old habits"(Hutchins et al., ibid., p.8).

- (حزُّ في):to hurt(Ba'albaki, ibid., p.466). The components of the combination have a different meaning than when the particle is eliminated; in this case, the meaning is (to cut قََََ), hence the current MWV is idiomatic.

22. " سلّّمي إلى الله, فكلُ ما جاءولكِ من عنده ".

" Submit to God's will and to whatever He sends you"(Hutchins et al., ibid., p. 10). 
- (ستلَّمَ إلىى)(Al-Ahmedi, ibid., p.160): to accept (Ba'albaki, ibid., p. 641). The aforementioned MWV is a fixed statement whose meaning is not predicted from the meanings of its constituent components; consequently, it is an idiomatic multi-word verb. The results of applying the conditions provided by the practical model show that there is a term that may replace the MWV, which is (agree to رَضيَ). In addition, leaving off the preposition alters the verb's meaning.

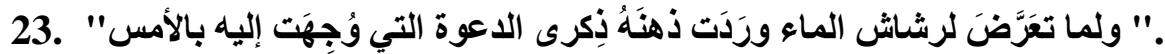

"As the spray of water hit him, he remembered the invitation he had received the day before"( Hutchins et al., 1991, p. 10).

- (تَعَرَّض لـ (Al-Ahmedi, 1979, p.233): to become exposed to (Ba'albaki, 1995, p. 337). This MWV is idiomatic; it has a meaning that differs from the meaning of the pieces of the construction taken separately. This MWV has a synonym to indicate that it is an idiomatic MWV (subject to وجَج). Moreover, removing the preposition changes the meaning of the verb.

- (وُجَّهُ لـ(Al-Ahmedi, ibid., p. 423): to send to (Ba'albaki, ibid., p. 1224). The present MWV is an idiomatic phrase whose meaning is derived from the combination of the verb and the preposition, which results in an idiomatic meaning. However, the verb (وَجّه term to replace it, which is(ارسل). At the same time, removing the preposition changes the meaning completely.

\section{4. "لم يكن ما يدعو الى هذه العجلة مادام احُ منهم لن يذهب إلى الحمام قبل عودة الأب منه"}

"In his opinion there was no need for this haste, since neither of them could venture to the bathroom until their father had left it"(Hutchins et al., ibid., p. 12).

- (دعا الى)(Al-Ahmedi, 1979, p. 100): to prompt (Ba'albaki, 1995, p. 543). This MWV has an idiomatic meaning that differs from the same verb when coupled with another preposition, such as (to curse دعا على (د) . Another word that may be used in place of this MWV to demonstrate its idiomatic status is (to prompt دَفَ).

- ( ذهبَ إلى (Al-Ahmedi, ibid., p. 112): to go to (Ba'albaki, ibid., p. 564). The verb is coupled with a preposition (to) and used literally, and the verb's meaning is incomplete without such a preposition. Because, as previously stated, both components of the combination retain their respective lexical meanings, the construction is referred to as non-idiomatic.

25. "الدور الاول الذي لم تعد تدخله قام إلا حين يلم بالبيت زائر ".

"the lower level, where no one set foot, except to entertain a visitor" (Hutchins et al., 1991, p. 12).

- (لََّّ (Al-Ahmedi, ibid., p. 334): pay a short visit to (Ba'albaki, ibid., p. 163). The MWV in this case is semantically idiomatic, which means that the components of the construction are fused together, creating a new meaning, and when separated, the meaning changes, and there is a word to substitute for this MWV, which is ( visit زار). In fact, eliminating the particle results in a shift in meaning.

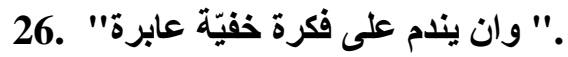

"to repent for this passing thought he kept secret "(Hutchins et al., ibid.).

- (نَّدمَ على)( Al-Ahmedi, ibid., p. 374): To repent of (Ba'albaki, ibid., p. 1164). In relation to what was previously said, (نَدَح على) is a non-idiomatic MWV formed by a verb and a preposition. Similarly, the preceding verb is a non-separable transitive verb.

27. "ثم اشترك حسين واسماعيل وحسن في حديث عن منيرة".

"Husayn, Isma'il, and Hasan all got involved in a conversation about the outstanding musicians of the day: Munira"(Hutchins et al., 1991, p.17).

- (اشنَرَكَّ في)(Al-Ahmedi, 1979, 177): to participate in (Ba'albaki, 1995, p. 163). The verb is semantically non-idiomatic; it conveys the concept of involvement. Furthermore, this verb is a syntactically transitive multi-word verb made up of a verb and a preposition. However, as previously stated, it does require an object to fulfill the meaning and, despite its orthographic 
treatment as two different words, acts essentially as a single-word verb and as a typical transitive verb.

28. "لم يكن قولاً, ولكن نغماً وسحراً استقرَ في الاعماق كي يُغَرِد دوماً بصوت غيرُ مسموع ينصُبُ فؤادكَ اليه ".

" It was not a phrase but a magical tune that came to rest deep inside you where it sings on silently to an attentive heart"(Hutchins et al., ibid., p.17).

- (استقر في): to settle down (Ba'albaki, ibid., p. 97). The verb is semantically non-idiomatic; it alludes to settling down. Furthermore, this verb is a syntactically transitive multi-word verb made up of a verb and a preposition. In actuality, it is a transitive verb that requires an object to fulfill the meaning.

29. "كان مظهر الاخوين يدلٌ على الادب والخشوع, ولكن خلا قلبهما من الخوف الذي كان يركبهما قديماً في حضرة الاب ل.

" Although the two brothers appeared polite and submissive, their hearts were almost free of the fear that had afflicted them in former times in their father's presence"( Hutchins et al., ibid., p. 19).

- (دلَّ على)( Al-Ahmedi, 1979, p. 103): to indicate (Ba'albaki, 1995, p. 548). When the components of the combination are joined, they take on a new meaning, and the entire meaning of the idiomatic MWV cannot be deduced from the lexical meanings of its constituent parts. This MWV can be checked for idiomaticity by substituting it with another word, such as (point out). اششارَ). And because missing the second component of the construction changes the meaning of the verb, it is an idiomatic MWV.

- (خلا من)(Al-Ahmedi, ibid., p.89): to be free from (Ba'albaki, ibid., p. 518). This expression is nonidiomatic one, in which the meaning is predictable from the meanings of its parts. This is a nonidiomatic expression whose meaning may be deduced from the meanings of its constituent components.

- (رَكَبَ في)(Al-Ahmedi, ibid., 135): to be afflicted with( Ba'albaki, ibid., p. 21). It is an idiomatic phrase in which the meaning is not predicted from the meaning of its pieces and they (the parts) act as a single unit in which the meaning cannot be obtained from the meaning of the individual elements. This MWV may be replaced with the term ( to afflict ابتلى), hence it is an idiomatic MWV. However, modifying or removing the preposition has an influence on or modifies the meaning.

30. "واتجهت إلى غرفة كمال وياسين فكررت الدعوة".

" Going to the room shared by Yasin and Kamal, she repeated her invitation"( Hutchins et al., 1991, p. 20).

- (اتجََ إلىى)(Al-Ahmedi, ibid., p. 424): go to (Ba'albaki, ibid., p. 28). This MWV's meaning is predicted from the meanings of its pieces, and the parts are employed in a non-idiomatic manner.

Table (4): AMWVs in "Palace of Desire" [Qasr Al-Shawq]

\begin{tabular}{|c|c|c|c|}
\hline No. & AMWVs & Semantic Type & Alternative Verb \\
\hline 1 & Kعلِمَ بـِ Know & Non-idiomatic & \\
\hline 2 & Affect نالَ مِن & Idiomatic & To affect \\
\hline 3 & Stop نَوَقِّتَ عن Stop & Idiomatic & Tفتَّ عن To quit \\
\hline 4 & غَرَسَ بِ & Non-idiomatic & \\
\hline 5 & Sign اومأ إلى Sign & Idiomatic & To signal اشَارَ To \\
\hline 6 & Hurt حَزّ في Hurt & Idiomatic & يُحزِنُ Make sad \\
\hline 7 & Accept & Idiomatic & Agree رَضيَ بـ \\
\hline 8 & نَعَرَّضَ لِِ Become exposed & Idiomatic & Subject to واجَهَ \\
\hline 9 & Sو وَجَّهَ لِ Send & Idiomatic & To send \\
\hline 10 & Prompt دعا إلى Prompt & Idiomatic & دَفَ prompt \\
\hline 11 & Go to ذَهَبَ إلىى Go & Non-idiomatic & - \\
\hline 12 & لَّ لَّ بـ Visit & Idiomatic & زارَ زار To visit \\
\hline
\end{tabular}




\begin{tabular}{|c|c|c|c|}
\hline 13 & Repent & Non-idiomatic & 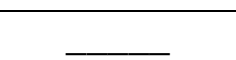 \\
\hline 14 & Participate اشنَرَكََ في & Non-idiomatic & \\
\hline 15 & Settle down أستَقَرَّ في & Non-idiomatic & \\
\hline 16 & Indicate دَلَّ على In & Idiomatic & Point out \\
\hline 17 & Be free & Non-idiomatic & \\
\hline 18 & Be afflicted with رَكَبَ في & Idiomatic & afflict \\
\hline 19 & Go to اتَجَهَ إلىى & Non-idiomatic & - \\
\hline
\end{tabular}

\section{Conclusions}

The primary goal of this research is to look at the occurrence of multi-word verbs as a phenomena in both English and Arabic. The other goal is to make a number of suggestions for English course designers, Arabic lexicographers, and pedagogues based on the findings of the empirical research undertaken in the study.

The study's fundamental premise is that there is a phenomena known as a multi-word verb in both languages. In this study, a series of research questions is offered to address the theoretical component of the thesis as well as to examine the data obtained from the semantic standpoints. In truth, there are significant parallels and variations in the semantic features of multi-word verbs between English and Arabic. However, the following conclusions can be drawn:

1. The term "multi-word verb" is exclusively used in English; (EMWVs) are generally employed in colloquial English, whereas Arabic verbs are more formal in conventional Arabic. According to the findings, (AMWVs) can be discovered under the categories (transitive verbs by means of a preposition; two-word verbs and verb-preposition idioms).

2. The studied verbs in both languages are semantically identical throughout the study of the forms and meanings of the verbs in the 30 quotes. In reality, there are similarities between the two languages since they both feature idiomatic, semi-idiomatic, and non-idiomatic phrases.

3. 3. As a consequence of the studied books, the number of AMWVs employed exceeds the number of English counterparts. EMWVs can be either transitive or intransitive, but Arabic ones are always transitive via a preposition. In both languages, they might be separate or inseparable.

4. English grammarians define "MWV" as a combination of a verb plus a preposition or an adverb. While Arabic grammarians describe a MWV as a verb that impacts one or two objects using prepositions, resulting in the verb's transitivity.

5. In English, transitive verbs take on varied meanings depending on the prepositions they are linked to, and the same is true in Arabic.

6. Like EMWVs, Arabic verb-preposition combinations can be non-idiomatic, semi-idiomatic, or idiomatic.

\section{References}

\section{English References}

- Abboud, P. F., \& McCarus, E. N. (1968). Elementary Modern Standard Arabic. United Kingdom: Cambridge University Press.

- Aldahesh, A. Y. (2008). Translating idiomatic English phrasal verbs into Arabic : a contrastive linguistic study. Unpublished thesis. University of Western Sydney.

- Aldahesh, A. Y. (2017). Qur'anic Idiomatic Phrasal Verbs: Their Syntactic and Semantic Properties. International Journal of Language and Linguistics. Vol. 4,No. 3. Sydney: The University of Sydney.

- Al-Khalaili, K. ( 1979 ). English Phrasal Verbs in Arabic. London: Hodder and Stoughton .

- Alkhuli, M. A. (1999). Comparative Linguistics: English and Arabic. Jordan: Alfalah House.

- Alkhutabi, H. M. A.; Alrumany ,A.A. ; Aljerjany, A.( 1548). Thalath Rasa'il Fi E'jaz AlQur'an. (Ahmad, M. K. A \& Salam, M. Z.). (Eds.). (1991). $4^{\text {th }}$ ed. Alqahera. Dar Alm'arif. 
- Bataineh, R. F., \& Bataineh, R. F. (2002). The Difficulties Jordanian Graduate Learners of English as a Second language Face When Translating English Idioms into Arabic. RASK, 16, 33-83.

- Celce-Murcia, M. Larsen-Freeman, D. (1999).The Grammar Book. (2 ${ }^{\text {nd }}$ ed.). USA: Heinle \& Heinle Publishers.

- Cowie, A. P. (1993). "Getting to grips with phrasal verbs". Vol. 9. issue (4). Cambridge University Press.

- Cowie, A. P. (1993). "Getting to grips with phrasal verbs". Vol. 9. issue (4). Cambridge University Press.

- Dixon, R. M. W. (1982). "The Grammar of English Phrasal Verbs". Australian Journal of Linguistics, 2, 1-42.

- Hart, C. W. (1990). The ultimate phrasal verb book New york: Congress Library.

- Heaton, J. B. (1965). Prepositions and Adverbial particles. London: Longman Group Limited.

- Kennedy, A. G. (1967). The Modern English Verb-Adverb Combination. New York: AMS Press Inc.

- Kharma, N., \& Hajjaj, A. (1989). Errors in English Among Arabic Speakers: Analysis and Remedy. London: Longman

- Kolln, Martha and Robert Funk. (2012) Understanding English Grammar. $5^{\text {th }}$ ed. Boston.

- Litvinov, A. V., Burikova, S. A., \& Khramchenko, D. S. (2017). Phrasal verbs as learning material in Business English courses for students majoring in Linguistics. Training, Language and Culture, 1(4), 84-98.

- Live, A. H. (1965). "The Discontinuous Verb in English". Word (21), 428-451.

- Machonis, Peter A. (2009). Compositional phrasal verbs with up: Direction, aspect, intensity. Lingvisticæ Investigationes 32:2, 253-264.

- Mahfuz, N. (1957). Qasr al shawq. (6 ${ }^{\text {th }}$ ed.) (2013). Egypt. Alqahera: Dar Alshorooq.

- McArthur, T. (1975). Using Phrasal Verbs (2 $2^{\text {nd }}$ ed.). London and Glasgow: Collins.

- McArthur, T.(Ed.). (1992). Oxford companion to the English language. Oxford/New York: Oxford University Press.

- McArthur, T., \& Atkins, B. (1974). Dictionary of English Phrasal Verbs and their Idioms. London and Glasgow: Collins.

- McCarthy, M., \& O'Dell, F. (2004). English phrasal verbs in use. . New York: Cambridge University Press.

- Murphy, R. (2012). English grammar in use. Cambridge: Cambridge University Press.

- Najiib, A. M. (2001). ?usus al-tarjamah(4 ${ }^{\text {th }}$ ed.). Alqahera: maktabat ?ibn siinaa.

- Nasir, K. G. (2015). English and Arabic Phrasal Verbs In four selected short stories. Journal of The Thi Qar Arts, 16(2), 320.

- Palmer, F. R. (1974). The English Verb .(2 $2^{\text {nd }}$ ed.). London: Longman.

- Parkinson, D. (2001). Oxford phrasal verbs dictionary: for learners of English. Oxford: Oxford University Press.

- Parrot, Martin.( 2010). Grammar for English Language Teachers. UK: Cambridge University Press.

- Quirk, R. \& Greenbaum, S. \& Leech, G. \& Svartvik, J. (1985). A Comprehensive Grammar Of The English Language. London: Longman.

- Quirk, R., \& Greenbaum, S. (1973). A University Grammar of English. London: Longman.

- Sawyer, J. H. (1999). Verb adverb and verb particle constructions: Their syntax and acquisition. Unpublished doctoral dissertation, Boston University. 
- Smeaton, B. H. (1977). The Phrasal Verb in English, by Dwight Bolinger. Cambridge: Harvard University Press, 1971. Pp. xviii 187. Canadian Journal of Linguistics/Revue canadienne de linguistique, Vol.22(1), 71-75.

- Sroka, K. A. (1972). The Syntax of English Phrasal Verbs. The Hague and Paris: Mouton.

- Steinbeck, J. ( 1952). East Of Eden. Penguin Book, New York: USA.

- Swan M. and C. Walter ( 2001 ). The Good Grammar Book. Oxford : O.U.P.

- Swierzbin, B. (1996). Word Order with Separable Phrasal Verbs. Unpublished master's thesis, University of Minnesota.

- Turton, N., \& Manser, M. (1985). The Student's Dictionary of Phrasal Verbs. London and Basingstoke: Macmillan.

- Wallace, M. J. (1981). Dictionary of English Idioms. Glasgow and London: Collins.

- Wright, W. (1996). A grammar of the Arabic language. Vol. 2. $3^{\text {rd }}$ ed. Cambridge University Press. UK. 